\title{
Youth Forum \\ Immigration Crisis in Texas: The Impact of the Exotic Axis
Deer on the Texas Hill Country
}

\author{
By Kenna Brooks
}

Editor's note: This paper is the 4th Place winner of the High School Youth Forum contest at the Society for Range Management Annual Meeting, February 2006, Vancouver, British Columbia, Canada.

exas is facing a serious immigration crisis. I don't mean the immigration of people, as is currently in the news, but the importation and proliferation of nonnative deer species, specifically the axis deer (Axis axis).

"We are the best of a bad example." These are the words of Wayne Haley, Superintendent of the South Llano River State Park. His words not only speak for the condition of the park, but serve as a reminder of the condition most of the area is in. The park is overpopulated with white-tailed deer and exotics, and struggles to provide enough forage to feed them. Additionally the Texas Hill Country is currently in the midst of a heavy drought, which compounds the problem.

The South Llano River State Park is located in Kimble County just outside the town of Junction in the heart of the Texas Hill Country. The Hill Country, or Edwards Plateau region, contains approximately 24 million acres and is located in the southwestern part of the state. Junction, located at the confluence of the North and South Llano rivers, has an elevation of 1,750 feet, and an average annual rainfall of only 22 inches per year. Located approximately 150 miles west of Austin, Junction is accessed by US Highway 83, Interstate 10, and US Highway 377.

Historically an agricultural and ranching area, the Hill Country is being transformed into a popular place to visit for recreation, and to retire. The hunting of white-tailed deer, Rio Grande turkey, white wing and mourning dove, and more recently the exotic imports, brings a significant increase in the number of visitors, and has become the major source of income in the local economy. River activities such as fishing, canoeing, tubing, and kayaking bolster

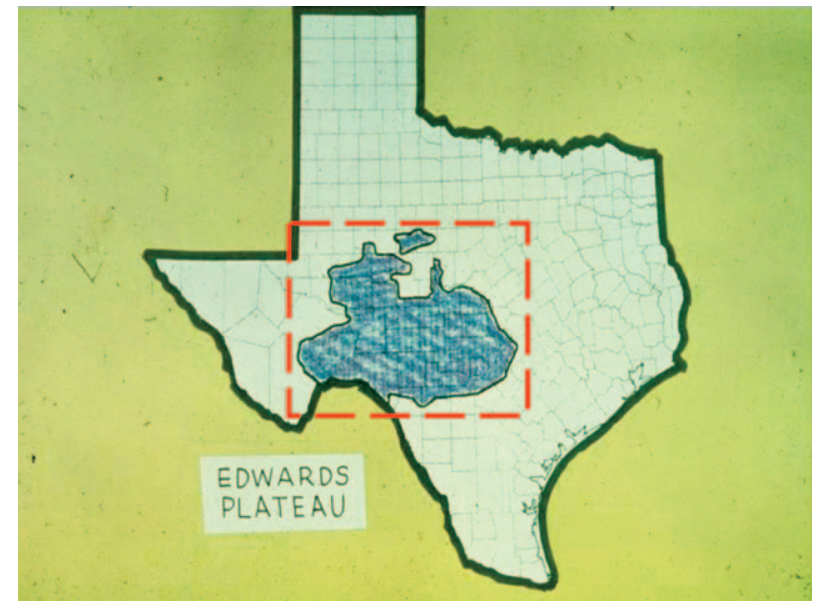
the increasingly tourist-oriented atmosphere. Because of the gaining popularity of the area, property values have risen over the past decade, and the use of the land is steadily shifting from agriculture to recreation.

With this change to increased recreational land use, ranches are being subdivided into smaller tracts, and many landowners look to hunting as a source of income. A number of these landowners have also added the hunting of exotics in order to boost that in- 


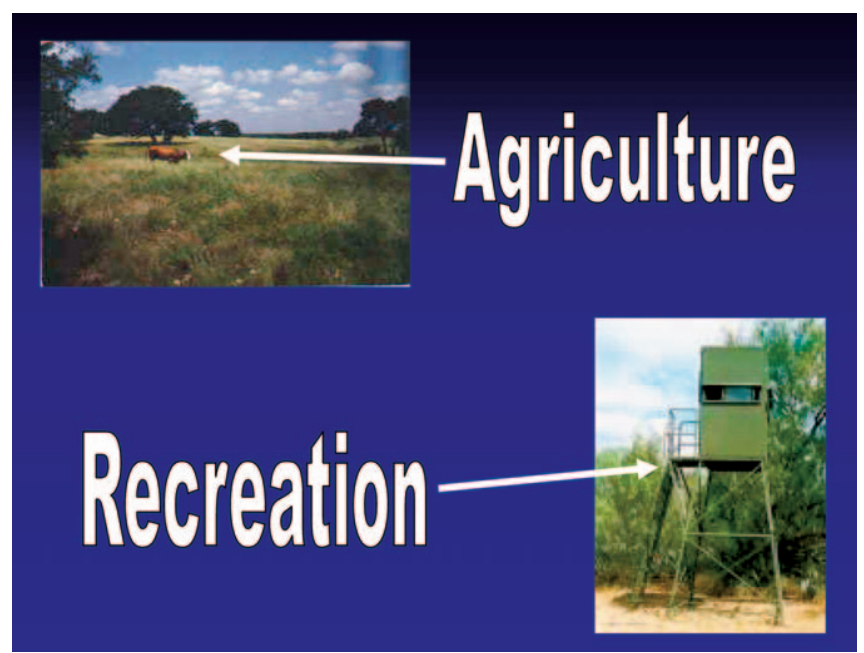

come, and in some cases to hang on to the family ranch. Exotic species are very attractive to hunters because they make fine trophies and they can be harvested year-round. Exotic animals in Texas are not regulated like the native game species are. White tails can only be hunted for roughly 2 months in late fall and early winter. Year-round hunting of exotics allows for more income outside of the regulated hunting seasons.

The most numerous of all exotics in the Texas Hill Country is the axis deer. The first known stocking of the axis deer

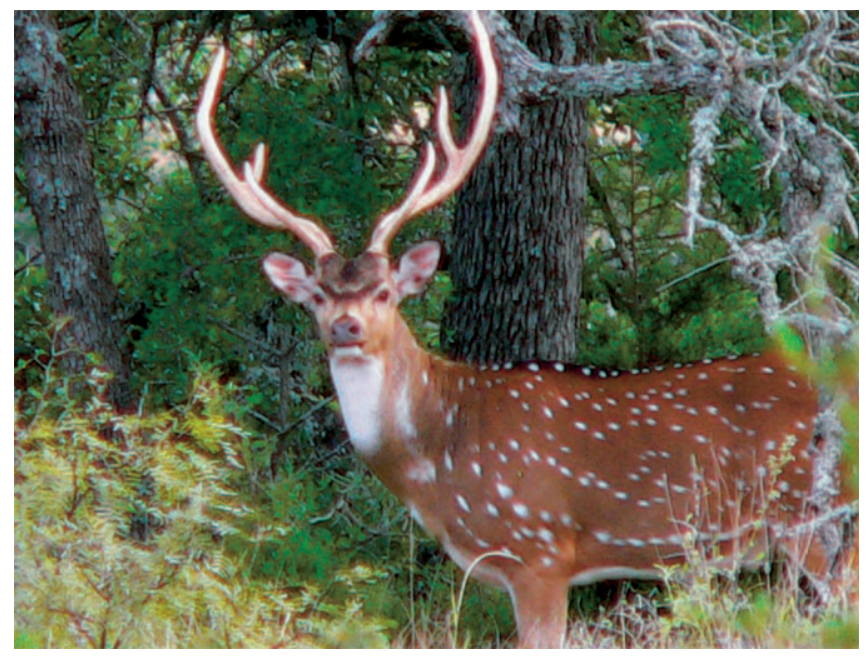

in Texas was in Kerr County in 1932. Axis deer, also known as chital deer, or Indian spotted deer, are native to India and have a bright reddish coat with white spots that are arranged in rough lateral rows along the body of the deer. Adult males differ in coloration from females in that their coats are darker and they have black facial markings. Axis deer are much larger than white-tailed deer, and have a stockier build. Males often exceed 200 pounds live weight, and females weigh approximately 35 percent less. In contrast, white tail males in the Hill Country will rarely exceed 110 pounds. The antlers of the axis are large and massive, yet simple in design, and can reach lengths of over 40 inches, making them an attractive wall mount.
Axis deer also produce much more meat than the white tail. Axis are a tropical species, and they do not put on fat, therefore there is no marbling in the meat. The meat is lower in calories, fat, and cholesterol than either beef or chicken, and is high in protein. Axis venison has an excellent flavor, and doesn't have the "gamey" taste that is unappealing to some consumers.

In the Hill Country area, axis deer compete both directly and indirectly with white-tailed deer. The white tail's diet consists mainly of forbs and browse, with grass making up a very small percentage, most of it consumed in the spring. Axis deer prefer forbs and browse as well, placing them in direct competition with the white tail. But when forbs and browse become in short supply, as is often the case with the Hill Country climate and range conditions, axis become like cows. They switch over to grass and do very well on it, while the white tails starve due to a lack of forage. White tails, being selective feeders, cannot digest mature grass, and can die with a rumen full of it. The cellulose in mature grass cannot be broken down in the short amount of time that food is contained in the white tail digestive tract. The axis, which is an intermediate feeder, is able to shift to a new food source when others become unavailable, giving them a major advantage over the less efficient white tail.

Axis have no particular breeding season and reproduce year round. Axis females can be bred while still lactating, which means axis can multiply at a faster rate. In comparison, white-tailed deer are restricted to a single breeding season during the late fall and early winter. The Hill Country can experience very cold, dry winters, which coincide with the gestational period of the white tail, and these harsh conditions can severely limit fawn production. The reproductive differences between the 2 species contribute to the continually increasing numbers of axis deer in the Hill Country, and are an example of indirect competition with the white tail.

Studies conducted in the Kerr Wildlife Area confirmed that axis deer could out-perform the white tail when an equal number of each species were placed together with only native vegetation to survive on. At the conclusion of the study the axis population was 5 times greater than the white tail population. There is evidence in this study to suggest that the Hill Country could lose much of its native population if current conditions and range management are not improved.

The appearance of Hill Country rangelands is very different today compared to 150 years ago. The vast grasslands, which were covered with an occasional bunch of live oak, have disappeared. Midgrass and tallgrass communities have been replaced with shortgrass communities, and unfavorable vegetation has spread from the steep draws and canyons to cover a majority of the rangelands.

These changes began to occur when settlers moved into the Hill Country with sheep, goats, and cattle, taking advantage of the lush grasslands and eventually overgrazing them. This overgrazing allowed unfavorable forage to grow and spread. Additionally, wildfires that would naturally occur 
every 1 to 6 years kept unfavorable growth in check and put nutrients back into the soil, benefiting the grasses. Efforts to control natural wildfires have been successful, but have resulted in a huge increase of plants such as mesquite, live oak, shin oak, Ashe juniper, and a wide range of forbs.

The change of the land from grassland to a more brushtype habitat also encouraged the increase in a previously small white-tailed deer population. White-tailed deer thrive in areas with food and cover, and the numbers of deer increased proportionately with the increase in brush and weeds. It has been estimated that at the turn of the century there was roughly 1 white tail per 40 acres. Present day estimates place that ratio at 1 deer per 8 acres. The Edwards Plateau area supports the largest deer population in North America.

The greatest concerns between white tail and axis are those of overcompetition for this habitat. Earlier in this paper I mentioned some of the current problems faced in the Hill Country, the main ones being drought, overpopulation, and poor range management. As of right now there are too many deer in the Hill Country for a sound ecosystem to exist between axis and white tail. There is not a steady food supply for the native white tail; therefore a majority of them starve from time to time, sometimes leading to increased death rates. Another byproduct of forage shortage is the declining size of white-tailed deer in the Hill Country.

Decades ago, as hunting began to gain popularity, landowners were encouraged to preserve female white tails so that the population would grow. The state placed harvest limits on does according to the size of the ranch, and hunters were severely limited on doe bag limits. Landowners are now encouraged to reduce the doe population, and hunters are allowed to take up to 5 does in some counties. Following the regular season, some areas in Texas are allowed an additional 2 weeks to harvest excess does. Only so many animals can occupy a certain space of land, and we have pushed the limit. Now we must pay the price by watching the native population suffer while the exotics continue to thrive.

The solution is management. If white tails and axis are to interact successfully, a cooperative management plan must be implemented, incorporating food plots which provide enough forage for both species to coexist. Species populations should be monitored and controlled by harvesting so that neither species can overpopulate and overrun the ecosystem. Prescribed burning should be utilized on a normal basis rather than remaining an experimental range management device. Supplemental feeding and deer feeders should be used during times of stress, but should not be used to replace good range management practices.

I'm concerned today that many landowners have their priorities reversed, placing game management over range management. Installing deer feeders and building a high fence may produce more income, but these changes may have a detrimental effect on our native species. Complete containment of individual herds of white-tailed deer inside of game fences for extended periods can cause genetic deficiencies

\section{Game Management?} Or

\section{Range Management?}

within that herd. Unless new bloodlines are introduced on a regular basis, mutations will occur in that population that could eventually be passed on to the general white tail population outside of the contained area.

Property owners must be educated if the condition of the Hill Country is to be improved. Programs need to be utilized for the dispersal of vital information on the current status of the area and how to improve it.

As with many things it is easier to cause a problem than to fix one. A complete reversal of the immigration of axis deer to the Hill Country is not possible. They are here to stay, and in large numbers. The actions of our forefathers changed the landscape, stimulating the currently excessive white-tailed deer population. The more recent invasion of axis is now threatening to alter that equation. Whether this is a change for the better or a change for the worse depends on the perspective and motives of the individual. Whatever steps we take from here forward will produce more change, for change is inevitable. I do believe, however, with proper education and a concerted effort, a workable balance of axis and white tail can be achieved. This is a long-term goal, but with many small steps, and the help of others, it may one day succeed.

Author is an incoming junior at Junction High School in Junction, Texas, treefrog_2008@yahoo.com. She is a member of the Junction FFA, Kimble County 4-H, and SRM, and took 1st place at the 2006 Texas 4-H Roundup at Texas AEM University.

\section{References}

The Kleberg Studies in Natural Resources, The Axis

$$
\text { Deer in Texas }
$$

Society for Range Management

Exotic Wildlife Association

Texas Parks and Wildlife Department

Kerr Wildlife Management Area

Wayne Haley, South Llano River State Park

Texas Cooperative Extension (TAMU)

Charles Taylor, Texas A\&M University Research Station, Sonora, TX 